\title{
Determinants of Anemia among Early Adolescent Girls in Kendari City
}

\author{
Irfa Ekasanti*, Annis Catur Adi, Mardiyono Yono, Fifi Nirmala G, Muhammad Atoillah Isfandiari
}

\begin{abstract}
Background: Adolescent girls' anemia is a public health challenge. Anemia has an impact on cognitive abilities to reduce intelligence and results in adolescent achievement is down.

Objective: The purpose of this study was to analyze the determinants of anemia in early adolescent girls in Kendari City. Methods: This study used a cross-sectional design with a sample of 97 students. Data on parental characteristics, breakfast habits, nutritional status, menstrual status, and history of infectious diseases were collected by interview using a questionnaire. Data on nutrient intake (iron, protein, vitamin C) obtained through the $2 \times 24$ hour recall method then compared to the Indonesian standard (AKG). Hemoglobin level was measured using the EasyTouch heamoglobin meter device. Data analysis was done by chisquare analysis and multiple logistic regression analysis.

Results: The results showed $28.9 \%$ of adolescent girls had anemia. The results of chi-square analysis obtained that there was a relationship between the incidence of anemia on mother's education $(p=0.010$,), parental income $(p=0.017)$, iron intake $(p=0,000)$, protein intake $(p=0,000)$, vitamin C intake $(p=0.023)$, breakfast habits $(p=0.006)$, menstrual status ( $p=0.007)$ and history of infection diseases $(p=0,000)$. While the results of multiple logistic regression analysis obtained that there was a relationship between iron intake $(p=0.005, O R=3.009)$, protein intake $(p=0.007, O R=2.012)$, vitamin $C$ intake $(p=0.038, O R=1.167)$, menstrual status ( $p=0.002, O R=3.181)$ with anemia.

Conclusion: The dominant determinant of anemia in early adolescent girls in Kendari City is menstrual status. It is recommended to intervene in risk factors (mother's education, parental income, iron intake, protein, vitamin C, breakfast habits, menstrual status and history of infectious disease) to reduce the prevalence of anemia among adolescent girls.
\end{abstract}

Keywords: anemia determinant, adolescent girls, menstrual status, nutritional intake

*Correspondence:

Irfa Ekasanti

Email: irfaekasanti-2018@fkm.unair.ac.id

Fakultas Kesehatan Masyarakat, Universitas Airlangga Kampus C, Mulyorejo, Surabaya-60115, Jawa Timur, Indonesia

\section{INTRODUCTION}

The incidence of anemia in developing countries is still a public health problem, including Indonesia. About $27 \%$ of adolescent girls have anemia in developing countries. ${ }^{1}$ Anemia in the adolescent age group is characterized when the hemoglobin level does not reach 12 $\mathrm{g} / \mathrm{dL}$. In Indonesia there is an increase in the prevalence of anemia in adolescent girls. Based on Riskesdas 2013 the prevalence of anemia in adolescent girls, namely $37.1 \%$, increased in 2018 to $48.9 \%$. Saimin et al. (2018) at SMU Negeri 8, Nambo Village, Kendari City, found that the hemoglobin level in the anemia category was $75.8 \%$.

Anemia as a public health problem affects about $20 \%$ of maternal and newborn deaths. Anemia also has an impact on decreasing work productivity and limitations in cognitive development so that school achievement decreases.5 Hasanah's research (2015) proves that low student biochemistry learning outcomes result from high levels of anemia severity. 6 Another study states that hemoglobin levels are significantly related to children's intellectual intelligence, an increase of 1 gram in the percentage of hemoglobin levels can increase the intellectual intelligence of children by 6-7 points.7 In addition, anemia causes low concentration of children, resulting in less than optimal children's learning achievement.

Young women are a group that has a greater risk of developing anemia than young men. This is because the need for nutrients, including iron, increases with menstruation. Menstruation every month experienced by young women allows blood loss in large quantities. Research conducted by Tesfaye, et al (2015) on adolescent girls in Ethiopia found a significant relationship between menstrual status and the incidence of anemia. Teenage girls who have menstruated are more likely to have anemia than girls who have not menstruated.9 Another risk factor for anemia is a history of infectious diseases.

Infectious diseases such as malaria, schistosomiasis, and worms affect absorption and increase the loss of iron from the body.10 Research conducted by Ansar et al. (2014) stated that malaria parasite infection is very likely to cause 
anemia because in the invasion process in the body, plasmodium involves the function of blood cells red. The involvement of red blood cells in parasite invasion can be seen from the low hemoglobin level and the high prevalence of anemia in adolescent girls who have a history of malaria in the last three months.

The next risk factor is nutritional status. Research conducted by Chalise, et al (2018) found that adolescents who have a body mass index in the thin category are more likely to experience anemia 1.20 times compared to adolescents who have a body mass index in the fat category.11 Good nutritional status for a person, including young girls will contribute to their health as well as their ability to recover. If the nutritional status is not normal, it is feared that the iron status will also not be good, thus affecting the occurrence of anemia.

In addition, the most common cause of anemia is iron deficiency anemia. The high prevalence of iron deficiency anemia usually occurs due to the low intake of food that is needed by the body, especially iron which is the main component of hemoglobin which functions to synthesize hemoglobin. Other nutrients that have an important role are protein and vitamin C. Protein carries oxygen from the blood and binds to hemoglobin, while vitamin C helps the absorption of iron in the body. Lack of protein and vitamin $\mathrm{C}$ intake will have an impact on iron levels in the body.12 Research conducted by Syatriani \& Aryani (2010) found a relationship between consumption of iron, protein and vitamin $\mathrm{C}$ with anemia in junior high school students in Makassar City. ${ }^{13}$

The habit of eating breakfast is also a risk factor for the incidence of anemia in adolescent girls. Research conducted by Ansar et al (2014) found that young women who did not eat breakfast showed a lower mean hemoglobin $(12.03 \mathrm{~g} / \mathrm{dl})$ compared to those who used to eat breakfast $(12.63 \mathrm{~g} / \mathrm{dl})$. This study also found that girls who were not used to breakfast were more likely to experience anemia (44.3\%) than girls who used to eat breakfast $(26.5 \%)(p=0.006) .^{14}$

Socio-economic factors such as education and income can also influence the incidence of anemia. Listiana's research (2016) found that young women with low family income have a 2,442 times chance of getting anemia compared to young women with high family income.15 Girls with low family income are more likely to have anemia than girls with high family income, this is This is because families with high incomes have the ability to buy food and make it easier to choose food ingredients or types of dishes to be served. An increase in income will have an effect on improving health and family conditions, which in turn are related to nutrition, including anemia status. This study also explains that young girls with low maternal education tend to be anemic compared to girls whose mothers have high education.15 Educational factors also determine whether a person is easy to absorb and understand the nutritional knowledge they get. So that education is needed so that someone is more responsive to nutritional problems in the family and can take action as soon as possible.

Based on the description above, the aim of the study was to analyze the determinants of early adolescent anemia in Kendari City.

\section{METHODS}

The type of research used in this study is an analytic observational study using a cross sectional design. The place for data collection was carried out at SMPN 15 Kendari, with the data collection time being June-July 2019. The research population was students of SMPN 15 Kendari, with a population of 127 people. The sample size was determined using the formula from Slovin and obtained 97 early female adolescents who were sampled in this study. The sampling method used was simple random sampling.

The dependent variable is the incidence of anemia. Data on the incidence of anemia were measured using an easy touch hemoglobin meter by the Mokoau Health Center staff. Classification of anemia is if the $\mathrm{Hb}$ level is less than $12 \mathrm{~g} / \mathrm{dL}$ and there is no anemia if the $\mathrm{Hb}$ level is more than or equal to $12 \mathrm{~g} / \mathrm{dL} .16$ While the independent variables studied were parental characteristics (mother's education and parents' income), nutrient intake (iron, protein and vitamin C), breakfast habits, nutritional status, menstrual status, and a history of infectious diseases (worms and malaria). Parental characteristics data were obtained using a questionnaire covering maternal education with a low classification if not completing 9 years of compulsory education and high if completing 9 years of compulsory education and parents' income is categorized as low if $<U M K$ Kendari City and sufficient if $\geq$ UMK Kendari City (Rp. $.2,551,463) .17,18$. Nutritional intake data was measured using the $2 \times 24$ hour recall method, while to see the nutrient intake, it was processed using Nutrisurvey software. The results of nutrient intake were compared with the RDA. Iron and vitamin $\mathrm{C}$ are classified as deficient if $<77 \%$ and sufficient if $\geq 77 \%$ of the RDA19, while the classification for protein is less if $<80 \%$ and sufficient if $\geq 80 \%$ of the RDA20. Data on breakfast habits are obtained through interviews with young women, namely eating activities that are routinely carried out before leaving for school with the classification of often (4-7 times / week) and sometimes (23 times / week) .15 Nutritional status data is obtained by how to measure height using a microtoise with an accuracy of $0.1 \mathrm{~cm}$ and measuring body weight using a weighing scale with an accuracy of $0.1 \mathrm{~kg}$. Nutritional status was assessed using the BMI / $\mathrm{U}$ anthropometric indicator.21 Menstrual status data were obtained from interviews with young women who had menstruation and had not yet menstruated. have a history if you have not had any infections (worms and malaria) in the last 3 months

Analysis of data to see the relationship between variables, namely the dependent and independent variables using chi-square analysis, while to determine the dominant factor in anemia using multiple logistic regression analysis. The analysis was performed using SPSS Statistic Variation 21 software. 


\section{RESULT AND DISCUSSIONS}

\section{Anemia}

Adolescent anemia is defined as a condition when the hemoglobin $(\mathrm{Hb})$ level is less than normal. The normal limit of hemolglobin in young women is $12 \mathrm{gr} / \mathrm{dL}$. 16 Table 1 shows that $28.9 \%$ of early adolescent girls at SMPN 15 Kendari have anemia. A similar study conducted by Dumilah \& Sumarmi (2017) at Bina Insani Superior Junior High School showed that $21.4 \%$ of students had Hb levels below $12 \mathrm{gr} /$ $\mathrm{dL}$ and had anemia. ${ }^{8}$

Table 1.Frequency Distribution of Respondents Based on the Incidence of Early Adolescent Anemia in Kendari City

\begin{tabular}{lcc}
\hline \multirow{2}{*}{ The occurrence of anemia } & \multicolumn{2}{c}{ Total } \\
\cline { 2 - 3 } & $\mathbf{n}$ & $\mathbf{\%}$ \\
\hline Yes & 28 & 28.9 \\
\hline No & 69 & 71.1 \\
\hline Total & 97 & 100 \\
\hline
\end{tabular}

Parental education is the main source to support the family economy and to prepare the food menu for the family. The higher Parental education, the better she knows health information to meet her family nutritional needs such as the ideal level of energy, protein, iron, vitamin A and vitamin $C$ consumption ${ }^{23}$. The research which was done by Srivastava, et al (2016) among early adolescent girls in rural areas of Amroha district, Uttar Pradesh, India found a relationship between maternal education and the incidence of anemia in adolescent girls $(p=0.007) . .^{24}$

The analysis results showed $(p=0.017)$ a significant relationship between parental income and the incidence of anemia among early adolescent girls in Kendari City. In addition, an $\mathrm{OR}=3,978$ value was obtained, that means early adolescent girls with parent's income $<$ Rp. 2,551,463 are 3.978 times more at risk of developing anemia than others with parents' income $\geq$ (Rp. 2,551,463). The low income parents has limitations in nutritious food preferences such as iron, protein dan vitamin $C$ that will be served to the family. The high income parents will improve the family health condition related to nutrition, including affecting the anemia status in children. Research conducted by Kibret, et al (2019) in Ethiopia found that the low income category is a determinant for the incidence of anemia. ${ }^{25}$ Harding et al. (2017) research states the prevalence of anemia is significantly higher for women from the poorest family in Pakistan. ${ }^{26}$ the other research in the Tangail area of Bangladesh that was conducted by Miah, et al. (2014)
The incidence of anemia is influenced by several factors. According to Listiana (2016) mother's education, family income, knowledge, body mass index, intake of iron supplements and menstrual conditions are factors that influence the incidence of anemia. ${ }^{15}$ Sholicha \& Muniroh (2019) also found that the intake of nutrients such as protein, iron and vitamin $C$ is associated with the incidence of anemia in adolescent girls. ${ }^{12}$

\section{Determinant of Anemia Incidence Among Early Adolescent Girls in Kendari City}

Table 2 shows the statistical test results on the determinants of anemia in early adolescent girls in Kendari City. Parental characteristics include parental income and education. The analysis results showed there is a significant ( $p=0.010$ ) relationship between parental education and the incidence of anemia among early adolescent girls in Kendari City. In addition, an $\mathrm{OR}=3,600$ value was obtained, that means early adolescent girls who had uneducated mothers are 3,600 times more at risk of developing anemia than them who had well-educated mothers.

also found a relationship between the incidence of anemia and monthly parental income, by identifying adolescents with family monthly income in the category less at risk of developing anemia. ${ }^{27}$ The study by Sadeghian et al. (2013) also found family low income 3.35 times more at risk of developing anemia. ${ }^{28}$

Nutritional intake in this study included protein, iron and vitamin C intake. In addition, an $O R=11.494$ value was obtained, that means early adolescent girls with less iron intake are 11.494 times more at risk of developing anemia when compared to girls with adequate iron intake. As the main component of hemoglobin, iron functions for hemoglobin synthesis. Research by Lee, et al (2014) found a significant relationship between iron intake and the incidence of anemia. ${ }^{29}$ Iron is divided into heme and nonheme source iron. Heme iron is found in meat and can be absorbed up to $50 \%$, while non-heme iron is found in fruits, vegetables and dairy products but is strongly influenced by enhancers and inhibitors in its absorption. Research conducted by AlQuaiz, et al (2013) through multivariate logistic regression analysis revealed that infrequent meat intake ( $\leq 2$ times per week) had a 1.59 times more at risk of developing anemia than children who frequently ate meat every week ( $>2$ times per week). ${ }^{30}$ Saratha, et al (2010) also stated that the consumption of green leafy vegetables has a significant relationship with the anemia status of adolescent girls. Green leafy vegetables play a role in preventing anemia among adolescent girls. ${ }^{31}$ 
DOI: 10.2473/amnt.v4i4.2020. 271-279

Table 2. Analysis of Determinants of Early Adolescent Anemia in Kendari City

\begin{tabular}{|c|c|c|c|c|c|c|c|c|c|}
\hline \multirow{2}{*}{\multicolumn{2}{|c|}{ Parent Characteristics }} & \multicolumn{4}{|c|}{ The occurrence of anemia } & \multirow{2}{*}{\multicolumn{2}{|c|}{ Total }} & \multirow{3}{*}{ P-value } & \multirow{3}{*}{$\begin{array}{c}\text { OR } \\
(95 \% \mathrm{Cl})\end{array}$} \\
\hline & & \multicolumn{2}{|c|}{ Yes } & \multicolumn{2}{|c|}{ No } & & & & \\
\hline & & $\mathbf{n}$ & $\%$ & $\mathbf{n}$ & $\%$ & $\mathbf{n}$ & $\%$ & & \\
\hline Education & Low & 18 & 43.9 & 23 & 56.1 & 41 & 100 & \multirow{3}{*}{0.010} & \multirow{3}{*}{$\begin{array}{c}3.600 \\
(1.433-9.042)\end{array}$} \\
\hline & High & 10 & 17.9 & 46 & 82.1 & 56 & 100 & & \\
\hline Total & & 28 & 28.9 & 69 & 71.1 & 97 & 100 & & \\
\hline \multirow[t]{2}{*}{ Parents' Income } & $<U N$ & 23 & 38.3 & 37 & 61.7 & 60 & 100 & \multirow{3}{*}{0.017} & \multirow{3}{*}{$\begin{array}{c}3.978 \\
(1.356-11.676\end{array}$} \\
\hline & $\geq \mathrm{UN}$ & 5 & 13.5 & 32 & 86.5 & 37 & 100 & & \\
\hline \multirow[t]{2}{*}{ Total } & & 28 & 28.9 & 69 & 71.1 & 97 & 100 & & \\
\hline & & \multicolumn{4}{|c|}{ The occurrence of anemia } & \multirow{2}{*}{\multicolumn{2}{|c|}{ Total }} & \multirow{3}{*}{ P-value } & \multirow{3}{*}{$\begin{array}{c}\text { OR } \\
(95 \% \mathrm{Cl})\end{array}$} \\
\hline \multirow{2}{*}{\multicolumn{2}{|c|}{ Nutritional intake }} & & & & & & & & \\
\hline & & $\mathbf{n}$ & $\%$ & $\mathbf{N}$ & $\%$ & $\mathbf{n}$ & $\%$ & & \\
\hline \multirow[t]{2}{*}{ Zat Besi } & Low & 25 & 46.3 & 29 & 53.7 & 54 & 100 & \multirow{3}{*}{0.000} & \multirow{3}{*}{$\begin{array}{c}11.494 \\
(3.166-41.733)\end{array}$} \\
\hline & Eno & 3 & 7.0 & 40 & 93.0 & 43 & 100 & & \\
\hline Total & & 28 & 28.9 & 69 & 71.1 & 97 & 100 & & \\
\hline \multirow[t]{2}{*}{ Protein } & Low & 24 & 45.3 & 29 & 54.7 & 53 & 100 & & \\
\hline & Eno & 4 & 9.1 & 40 & 90.9 & 44 & 100 & 0.000 & $\begin{array}{c}8.267 \\
(2591-26.437)\end{array}$ \\
\hline Total & & 28 & 28.9 & 69 & 71.1 & 97 & 100 & & \\
\hline Vitamin C & Low & 20 & 40.0 & 30 & 60.0 & 50 & 100 & & \\
\hline & Eno & 8 & 17.0 & 39 & 83.0 & 47 & 100 & 0.023 & $\begin{array}{c}3.250 \\
(1259-8 \text { 387) }\end{array}$ \\
\hline Total & & 28 & 28.9 & 69 & 71.1 & 97 & 100 & & \\
\hline & & occurre & of an & & & & & & \\
\hline Breakfast Habits & & & & & & lotal & & -value & $(95 \% \mathrm{Cl})$ \\
\hline & $\mathbf{n}$ & $\%$ & $\mathbf{n}$ & $\%$ & $\mathrm{n}$ & $\%$ & & & \\
\hline Sometimes & 23 & 40.4 & 34 & 59.6 & 57 & 100 & & & \\
\hline Often & 5 & 12.5 & 35 & 87.5 & 40 & 100 & & 0.006 & 4.735 \\
\hline Total & 28 & 28.9 & 69 & 71.1 & 97 & 100 & & & \\
\hline & & occurre & of an & & & Catal & & & \\
\hline Status Giz & & & & & & lotal & & P-value & $(95 \% \mathrm{Cl})$ \\
\hline & $n$ & $\%$ & $n$ & $\%$ & $n$ & $\%$ & & & \\
\hline Abnormal & 6 & 40.0 & 9 & 60.0 & 15 & 100 & & & \\
\hline Normal & 22 & 26.8 & 60 & 73.2 & 82 & 100 & & 0.468 & $\begin{array}{c}1.818 \\
-580-5700)\end{array}$ \\
\hline Total & 28 & 28.9 & 69 & 71.1 & 97 & 100 & & & \\
\hline & & occurre & of an & & & Cotal & & D.alue & $O R$ \\
\hline Menstrual Status & & & & & & Iotal & & P-value & $(95 \% \mathrm{Cl})$ \\
\hline & $\mathbf{n}$ & $\%$ & $\mathbf{n}$ & $\%$ & $\mathbf{n}$ & $\%$ & & & \\
\hline Have Menstruation & 21 & 42.0 & 29 & 58.0 & 50 & 100 & & & \\
\hline Not menstruating & 7 & 14.9 & 40 & 85.1 & 47 & 100 & & 0.007 & $\begin{array}{c}4.138 \\
(1553-11024)\end{array}$ \\
\hline Total & 28 & 28.9 & 69 & 71.1 & 97 & 100 & & & \\
\hline & & occurr & e of at & & & $\Gamma$ & & & $O R$ \\
\hline History of Infectious & & & & & & rotal & & P-value & $(95 \% \mathrm{Cl})$ \\
\hline & $n$ & $\%$ & $n$ & $\%$ & $n$ & $\%$ & & & \\
\hline Have History & 14 & 73.7 & 5 & 26.3 & 19 & 100 & & & \\
\hline Has No History & 14 & 17.9 & 64 & 82.1 & 78 & 100 & & 0.000 & $\begin{array}{c}12.800 \\
(2059-41386)\end{array}$ \\
\hline Total & 28 & 28.9 & 69 & 71.1 & 97 & 100 & & & \\
\hline
\end{tabular}


This study also showed the average of iron consumption in adolescent girls was $6.7 \mathrm{mg}$ per day which is below the recommended daily need for iron, arround 8 mg per day for ages 10-12 years and $15 \mathrm{mg}$ per day for women aged 13-15 years. ${ }^{32}$ This study is in line with research conducted by Miah, et al (2014) who found that all anemic girls usually consume $5.21 \mathrm{mg}$ of iron per day which is insufficient to meet their daily needs. ${ }^{27}$ So it is very important to raise awareness about consuming more iron during adolescence to reduce the prevalence of anemia . Research conducted by Nelima (2015) on the determinants of anemia among high school girls in the Yala Division, Siaya District, Kenya found that iron intake that is not sufficient for daily needs is a determinant of anemia with a risk of 8.87 times compared to adolescents with adequate intake of iron nutrients. Although the average intake of iron nutrition in adolescent girls was above the nutritional adequacy level, most of them drank tea with food (97.4\%). The lunch menu at the school canteen is corn and beans mixture and a cup of black tea. ${ }^{33}$ Research conducted by Marina, et al. (2015) stated that tannins consumed from tea, calcium and phytate are some inhibitors of the iron absorption. As much as $64.7 \%$ of adolecents girls with low hemoglobin status consumed tannins more often than girls with normal hemoglobin status from the habit of consuming tea. The study also found a relationship between tannin intake from the habit of consuming tea on $\mathrm{Hb}$ status, the value of $\mathrm{p}=$ $0.013 .^{34}$

The analysis results showed $(p=0.000)$ a significant relationship between protein intake and the incidence of anemia among early adolescent girls in Kendari City. In addition, an $\mathrm{OR}=11.494$ value was obtained, that means early adolescent girls with low protein intake had an 8,267 times more at risk of developing anemia than girls with sufficient protein intake. Research conducted by Sholicha \& Muniroh (2019) found a significant relationship between protein intake and hemoglobin levels in adolescent girls, $p$ value $=0.000$. This study also found the results of the analysis from the Spearman correlation test between the variable protein intake and the anemia incidence variable with $r=0.663$, which means that the relationship between variables is quite strong. Akib \& Sumarmi's research (2017) also states that there is a relationship between the level of protein intake and the incidence of anemia $(p=0.027)$ using the person correlation test analysis.35 Protein also makes an important contribution in the body during the iron absorption process.

Iron absorption can be inhibited and lead to iron deficiency if protein intake is lacking. This is because protein is useful as a building and regulatory substance, besides that protein also regulates human health by providing molecular precursors of amino acids and also functions as a component in body cells, protein also has a role in the transportation of iron to the spinal cord for formation. red blood cells.36 Protein intake, especially in animal protein helps increase iron absorption, therefore low protein intake can affect $\mathrm{Hb}$ levels to be less, so that it can lead to anemia.
13 Research by Sholihah et al. (2019) found an effect of protein intake on anemia. with an OR-30.333 value, which shows that young women who have less protein intake are at 30.433 times greater risk of experiencing anemia than girls who have sufficient protein intake. This positive patterned relationship indicates that the $\mathrm{Hb}$ level will be high if the protein intake is also high. ${ }^{37}$

The results of this study also showed that the average protein consumption of young women was $48.7 \mathrm{~g}$ per day. This indicates that the respondents' daily protein requirements are below the recommended daily protein requirement, namely $50 \mathrm{~g}$ per day for ages $10-12$ years and $70 \mathrm{~g}$ per day for 13-15 years old for women.32 This study is in line with research conducted by Sholihah et al. (2019) who found that all anemic girls consumed an average of $44.17 \mathrm{~g}$ of protein per day which is not sufficient to meet their daily needs. ${ }^{37}$

The results of the analysis of vitamin C intake on the incidence of anemia showed $(p=0.023)$ a significant relationship between vitamin $C$ intake and the incidence of anemia in early adolescent girls in Kendari City. The results of the analysis also showed that the OR value of vitamin C intake was 3,250, which means that young women with vitamin C intake were 3,250 times less risky than young women with sufficient vitamin C intake. This research is in line with research conducted by Sholicha \& Muniroh (2019) which found that there is a relationship between vitamin C intake and hemoglobin levels in adolescent girls.12 Metabolism and absorption of iron are one of the functions of vitamin C. Eating foods containing vitamin C will make it easier reduce ferric iron to ferrous in the small intestine so that it is easily absorbed. In addition, to free iron reserves, vitamin $\mathrm{C}$ will inhibit the formation of hemosiderin which is difficult to mobilize.38 The absorption of iron in the nonheme form increases fourfold when there is vitamin $C$ which plays a role in moving iron from transferrin in plasma to ferritin in the liver.

The results of this study also showed that the average consumption of vitamin $C$ for young women was $42.3 \mathrm{mg}$ per day. This indicates that the daily requirement for vitamin $\mathrm{C}$ of respondents is below the recommended daily requirement for vitamin $\mathrm{C}$, namely $50 \mathrm{mg}$ per day for ages 10-12 years and $65 \mathrm{mg}$ per day for ages $13-15$ years for women.32 Research by Lee, et al stated that the incidence of anemia associated with low vitamin C intake or insufficient nutritional adequacy standards with the results of the analysis obtained a p-value $<0.001 .29$ Research conducted by Sholicha \& Muniroh (2019) also found that on average adolescent girls had less vitamin C intake, so that their levels hemoglobin in adolescent girls is below normal limits. ${ }^{12}$

The results of the analysis of breakfast habits on the incidence of anemia showed ( $p=0.006$ ) a significant, significant relationship between breakfast habits and the incidence of anemia in early adolescent girls in Kendari City. The results of the analysis also showed that the OR value = 4.735 , meaning that young women who sometimes eat 
breakfast before going to school have a 4.735 times risk of experiencing anemia than young women who often eat breakfast when going to school. A similar study was conducted by Sirajuddin \& Masni (2015) that students who only ate breakfast 2-3 times a week which was the occasional or infrequent category were at risk of developing anemia 2.95 times compared to students who had frequent breakfast habits.40 Eating habits In the morning before 9:00 a.m. will meet the daily nutritional needs of around $15-30 \%$ which allows the fulfillment of balanced nutrition in order to live a healthy life.41 Therefore, breakfast habits are one of the important behaviors in realizing balanced nutrition, including avoiding nutritional problems with anemia in adolescents. Factors that usually cause school children not to eat breakfast are because children need an earlier time to wake up, the lack of parental knowledge so they do not prepare breakfast and families do not get used to eating breakfast. Ummi \& Raden's research (2016) states that the habit of eating breakfast is one of the risk factors for anemia because breakfast determines adolescents to get a good intake as a provision for daily activities so that they avoid anemia.42 Balc, et al (2012) also found that Irregular eating habits are very important in the development of anemia in adolescents in Denizli, Turkey.43 When compared to young women who are accustomed to breakfast and who are not used to breakfast, it is found that more young women are anemic when they are not used to breakfast (44.3\%) than those who used to eat breakfast (26.5\%). The results of statistical analysis of nutritional status on the incidence of anemia showed ( $p=0.468)$ which was significant, there was no relationship between nutritional status and the incidence of anemia in early adolescent girls in Kendari City with $p=0.468$. This can happen because on average young women have normal nutritional status. A similar study was conducted by Jalambo, et al. (2013) among high school students in the Gaza Strip that the results of statistical analysis found no relationship between nutritional status and the incidence of anemia $(p=0.52) .44$ However, Chalise found different results. et al (2018) that adolescents who have a body mass index in the thin category are more likely to develop anemia 1.20 times than adolescents who have a body mass index in the fat category.

The results of the statistical analysis of menstrual status on the incidence of anemia showed $(p=0.007)$ that there was a significant relationship between menstrual status and the incidence of anemia in early adolescent girls in Kendari City. The results of the analysis also showed that the value of $O R=4.138$ was significant, adolescent girls who had menstruated had a 4.138 times risk of anemia than girls who had not menstruated. The results of this study were supported by Tesfaye et al. (2015) which stated that menstrual status was significantly associated among Ethiopian school adolescents with the incidence of anemia. Adolescents who have experienced menstruation have a 2.34 times risk of developing anemia.9 Another study conducted by Gupta et al. (2014) also found a significant relationship between the menstrual status of young women and the incidence of anemia. ${ }^{45}$
The results of statistical analysis of the history of infectious diseases (worms and malaria) on the incidence of anemia showed $(p=0.000)$ which had a significant relationship between the history of infectious diseases and the incidence of anemia in early adolescent girls in Kendari City. Statistical results also obtained $\mathrm{OR}=12.800$, which means that young women who have a history of infectious diseases (worms and malaria) have a 12.800 risk of developing anemia compared to girls who have no history of infection. This study is supported by Ramzi, et al (2011) who conducted a study on school-age adolescents in Kavar Urban Area, South Iran found that parasitic infections in the last three months had an anemia risk of 6.83 times compared to those without a history of infection. ${ }^{22}$

Parasitic infections such as malaria are very likely to cause anemia because in malaria the plasmodium parasite invades red blood cells then the presence of parasites in the blood triggers blood cell damage as a result of immune cell phagocytosis activity or erythrolysis as a result of parasitic activity.46 Research conducted by Ansar et al found that involvement Red blood cells in this parasite invasion are illustrated by low hemoglobin levels and high prevalence of anemia in adolescent girls who have had a history of malaria in the last three months.14 Anemia in malaria is caused by the massive destruction of red blood cells, one of which is caused by high parasite intensity. In severe malaria with levels of parasitemia $>5000 / \mu$ l of blood, severe anemia which can be life-threatening can occur. ${ }^{47}$

In addition, ascariasis activity, which is an infection caused by ascaris lumbricoides or commonly called roundworms, can also cause anemia. This is because ascariasis activity in the gastrointestinal tract can lead to impaired iron absorption in sufferers. The activity of ascariasis in the digestive tract causes damage to the intestinal mucosa and causes impaired iron absorption and blood loss in the intestines. In addition, ascariasis also competes with the body for iron, which causes a decrease in the body's absorption of iron which results in anemia. ${ }^{48}$

Nelima's research (2015) states that the factors that are related to the incidence of anemia in adolescent girls in high schools in the Yala Division, Siaya District, Kenya are the presence of malaria parasites with $\mathrm{OR}=3.68$ and ascaris eggs with $\mathrm{OR}=11.94 .33$. research by Siva, et al (2016) states that washing hands and using improper footwear are factors that support worm infection among adolescents which in turn will cause anemia. This study stated that the prevalence of anemia was higher in adolescents who only occasionally washed their hands after bathing at $43.8 \%$ and before eating $29.3 \%$. In this study also found that adolescents who rarely use footwear have a greater proportion of anemia (50\%) than adolescents who usually use footwear (19.8\%). ${ }^{49}$

\section{Dominant Factors of Early Adolescent Anemia in Kendari City}

The results of multiple logistic regression analysis shown in Table 3 obtained four variables related to the incidence of anemia in adolescent girls, namely protein 
intake, iron intake, vitamin $\mathrm{C}$ intake and menstrual status. Based on the results of the study, the most dominant variable was the menstrual status variable with a $p$-value $=$ 0.002 and $O R=3.181$, which means that young women who have menstruated have 3.181 times the chance to experience anemia than young women who have not experienced menstruation.

Table 3. Multiple Logistic Regression Analysis the Determinants of Early Adolescent Anemia in Kendari City

\begin{tabular}{lccc}
\multicolumn{1}{c}{ Variabel } & B & P-Value & EXP (B) / OR \\
\hline Protein Nutrient Intake & 0.482 & 0.007 & 2.012 \\
\hline Iron Nutrient Intake & 0.511 & 0.005 & 3.009 \\
\hline Nutritional intake of Vitamin C & 0.138 & 0.038 & 1.167 \\
\hline Menstrual Status & 0.591 & 0.002 & 3.181 \\
\hline
\end{tabular}

Menstruation is a discharge experienced by young women every month. Generally, in early adolescence, menstrual patterns are not regular. Early adolescent girls bleed excessively during menstruation due to imperfect or abnormal endocrine work. (2014) showed that the use of more than two pads per day during menstruation was significantly associated with the prevalence of anemia. This implies that an increase in the number of pads used per day reflects the amount of blood loss and during menstruation indicates heavy menstrual periods.50 Anemia was also significantly associated with menstrual cycle regularity. Cycles of less than 20 or more than 35 days are more likely in adolescent girls who have anemia. 51

In addition, Rupali \& Sanjay (2015) stated that heavy and long menstruation is known to cause anemia.51 Miah, et al (2016) stated that $35.48 \%$ of the anemia case group experienced menstruation for more than 5 days. The results of statistical tests proved that there was a relationship between menstrual duration and the incidence of anemia $(p=0.072) .27$ The same result was also found by Jalambo, et al. (2013) who stated that menstrual duration of more than 7 days was a risk factor for anemia.44 The incidence of anemia in Febrianti's study, et al (2013) found a significant relationship between the incidence of anemia and menstrual length. Menstruation more than 7 days experienced by $40 \%$ of students. Bleeding that is longer than normal is called menorrhagia. Menorrhagia results in abnormal egg maturation and secretion, polyps in the uterine wall, uterine fibroids, pregnancy complications, adenomyosis, taking certain medications, hormonal imbalances, or other medical conditions.

The volume of blood lost every month due to menstruation ranges from 30-50 cc per month. This results in women losing iron as much as $12-15 \mathrm{mg}$ per month or 0.4-0.5 mg per day for 28 days to 30 days. During menstruation, women not only experience iron loss but also experience basal loss, so if the total number of women per day experience iron loss as much as $1.25 \mathrm{mg} .53$ Losing a lot of blood during menstruation results in low iron in the body. This situation will be exacerbated if iron intake does not meet nutritional adequacy. Lack of protein and vitamin $C$ intake will also have an impact on the availability of iron levels in the body.5 Therefore, young women should focus on meeting their intake of nutrients (protein, iron and vitamin C) during menstruation.
The advantage of this research is the measurement of hemoglobin levels was carried out directly by experts from the Mokoau Community Health Center which covers SMPN 15 Kendari (the working area of the Mokoau Community Health Center), namely nurses so that their safety can be guaranteed. The next advantage is that the interview process is carried out by calling the respondent in turn in a separate room from the classroom so that it is more conducive and the respondent is more focused. While the drawback of this study is that the population cannot include class $X$ to class XII. This is due to the licensing from the school and the limited number of researchers to cover the research costs.

\section{CONCLUSION}

Based on the results of the study, it was concluded that the determinants of anemia were maternal education, parental income, iron, protein, and vitamin C intake, breakfast habits, menstrual status and a history of infectious diseases. Menstrual status is the most dominant determinant of anemia. Teenage girls who have menstruated have a 3.181 times more at risk of developing anemia than young women who have not experienced menstruation. Therefore, it is important for girls who are menstruating to pay more attention to their nutritional needs (protein, iron and vitamin C) so that they can meet the recommended nutritional requirements. School-based interventions on risk factors for anemianeed to be carried out to reduce the prevalence of anemia among adolescent girls.

\section{ACKNOWLEDGEMENT}

Researchers would like to thank the school principal, the principal of SMPN 15 Kendari, for permission to conduct research at SMPN 15 Kendari. The researchers also thank the students of SMPN 15 Kendari who have been willing to become respondents.

\section{REFERENSI}

1. WHO. Anemia Among Adolescent and Young Adult Women in Latin America and The Caribbean: A Cause for Concern. (2010). Available at: http://www.paho.org/hq/dmdocuments/2010/An 
emiaEngWEB.pdf. (Accessed: 6th December 2019)

2. Kemenkes RI. Hasil Utama Riset Kesehatan Dasar (Riskesdas) 2018. Badan Penelitian dan Pengembangan Kesehatan Kementerian Kesehatan RI (2018).

3. Kaimudin, N. I., Lestari, H. \& Rusli Afa, J. Skrining dan Determinan Kejadian Anemia pada Remaja Putri SMA Negeri 3 Kendari Tahun 2017. JIMKESMAS 2, 1-10 (2017).

4. Saimin, J., Hafizah, I., Wicaksono, S., Ashaeryanto \& Jamaluddin. Pemeriksaan Hemoglobin Siswi Sekolah Menengah Umum Negeri 8 di Kelurahan Nambo Kota Kendari. SNT2BKL-KH-2 498-502 (2015).

5. Briawan, D. Anemia: Masalah Gizi pada Remaja Wanita. (EGC, 2013).

6. Hasanah, U. Hubungan Anemia Defesiensi Zat Gizi Besi dengan Hasil Belajar Biokimia Mahasiswa Biologi FMIPA Unimed Tahun 2014. J. Kel. Sehat Sejah. 13, 29-36 (2015).

7. Kusmiyati, Y., Meilani, N. \& Ismail, S. Kadar Hemoglobin dan Kecerdasan Intelektual Anak. Kesmas Natl. Public Heal. J. 8, 115-118 (2013).

8. Dumilah, P. R. A. \& Sumarmi, S. Hubungan Kejadian Anemia dengan Prestasi Belajar Siswi di SMP Unggulan Bina Insani. Amerta Nutr 331-340 (2017).

9. Tesfaye, M., Yemane, T., Adisu, W., Asres, Y. \& Gedefaw, L. Anemia and iron deficiency among school adolescents : burden, severity, and determinant factors in southwest Ethiopia. Adolesc. Health. Med. Ther. 6, 189-196 (2015).

10. Agustina, E. E., Laksono, B. \& Indriyanti, D. R. Determinan Risiko Kejadian Anemia pada Remaja Putri Berdasarkan Jenjang Pendidikan di Kabupaten Kebumen. Public Heal. Perspect. J. 2, 26-33 (2017).

11. Chalise, B. et al. Prevalence and Correlates of Anemia Among Adolescents in Nepal : Findings from a Nationally Representative Cross-Sectional Survey. PLoS One 13, 1-11 (2018).

12. Sholicha, C. A. \& Muniroh, L. Hubungan Asupan Zat Besi, Protein, Vitamin C dan Pola Menstruasi dengan Kadar Hemoglobin Pada Remaja Putri Di SMAN 1 Manyar Gresik. Media Gizi Indones. 14, 147-153 (2019).

13. Syatriani, S. \& Aryani, A. Konsumsi Makanan dan Kejadian Anemia pada Siswi Salah Satu SMP di Kota Makassar. Kesmas Natl. Public Heal. J. 4, 251-254 (2010).

14. Ansar, Taslim, N. A. \& Jafar, N. Anemia pada Remaja Putri dalam Kaitannya dengan Malaria, Pola Konsumsi Pangan dan Status Sosial Ekonomi di Daerah Endemik Malaria. J. MKMI 85-89 (2014).

15. Listiana, A. Analisis Faktor-Faktor yang Berhubungan dengan Kejadian Anemia Gizi Besi pada Remaja Putri Di SMKN 1 Terbanggi Besar
Lampung Tengah. J. Kesehat. 7, 455-469 (2016).

16. WHO. Haemoglobin Concentrations for The Diagnosis of Anaemia and Assessment of Severity. Vitamin and Mineral Nutrition Information System Background 1-6 (2011). Available at:

http://www.who.int/vmnis/indicators/haemoglob in.pdf. (Accessed: 6th December 2019)

17. Kemendikbud RI. Undang-Undang Republik Indonesia Nomor 20 Tahun 2003 Tentang Sistem Pendidikan Nasional. (2003).

18. PerGub Sultra. Peraturan Gubernur Sulawesi Tenggara No. 38 Tahun 2019 tentang Penetapan Upah Minimum Provinsi dan Upah Minimum Sektoral Provinsi Sulawesi Tenggara Tahun 2020. (2019).

19. Gibson, R. S. Principles of Nutritional Assessment. (Oxford University Press, 2005).

20. WNPG, W. N. P. G. No Title. (Lembaga Ilmu Pengetahuan Indonesia, 2004).

21. Dirjend Bina Gizi dan Kesehatan Ibu dan Anak Kemenkes RI. Keputusan Menteri Kesehatan Republik Indonesia Nomor: 1995/Menkes/SK/XII/2010 Tentang Standar Antropometri Penilaian Status Gizi Anak. (2011).

22. Ramzi, M. et al. Anemia and Iron Deficiency in Adolescent School Girls in Kavar Urban Area, Southern Iran. Iran Red Crescent Med J 13, 128133 (2011).

23. Farida, I., Widajanti, L. \& Pradigdo, S. Determinan kejadian anemia pada remaja putri di Kecamatan Gebog Kabupaten Kudus tahun 2006. J. Gizi Indones. 2, (2014).

24. Srivastava, A., Kumar, R. \& Sharma, M. Nutritional Anaemia in Adolescent Girls : An Epidemiological Study. Int J Community Med Public Heal. 3, 808812 (2016).

25. Kibret, K. T., Chojenta, C., Arcy, E. D. \& Loxton, D. Spatial Distribution and Determinant Factors of Anaemia Among Women of Reproductive Age in Ethiopia : A Multilevel and Spatial Analysis. BMJ Open 9, 1-14 (2019).

26. Harding, K. L., Aguayo, V. M., Namirembe, G. \& Webb, P. Determinants of Anemia Among Women and Children in Nepal and Pakistan : An Analysis of Recent National Survey Data. Matern Child Nutr 1-13 (2017).

27. Miah, M. S. et al. Prevalence of Iron Deficiency Anemia Among Adolescent Girls and Its Risk Factors in Tangail Region of Bangladesh. IJRET 3, 613-619 (2014).

28. Sadeghian, M., Fatourechi, A., Lesanpezeshki, M. \& Ahmadnezhad, E. Prevalence of Anemia and Correlated Factors in the Reproductive Age Women in Rural Areas of Tabas. J. Fam. Reprod. Heal. 7, 139-144 (2013).

29. Lee, J. et al. Prevalence and Risk Factors for Iron Deficiency Anemia in the Korean Population : Results of the Fifth Korea National Health and 
Nutrition Examination Survey. J Korean Med Sci 29, 224-229 (2014).

30. Alquaiz, A. M. et al. Prevalence of Anemia and Associated Factors in Child Bearing Age Women in Riyadh , Saudi Arabia. J. Nutr. Metab. 10-16 (2013).

31. Saratha, A. et al. Prevalence of Anemia Among Young Adult Female Students in a Medical Teaching Institution in Pondicherry. Indian J. Matern. Child Heal. 12, 1-8 (2010).

32. Permenkes. Peraturan Menteri Kesehatan Republik Indonesia Nomor 28 Tahun 2019 tentang Angka Kecukupan Gizi yang Dianjurkan untuk Masyarakat Indonesia. (2019).

33. Nelima, D. Prevalence and Determinants of Anaemia among Adolescent Girls in Secondary Schools in Yala Division Siaya District, Kenya. Univers. J. Food Nutr. Sci. 3, 1-9 (2015).

34. Marina, Indriasari, R. \& Jafar, N. Determinan Penyebab Anemia Pada Remaja Putri Di SMA Negeri 10 Makassar. J. MKMI 50-58 (2015).

35. Alfishar, A. \& Sumarmi, S. Kebiasaan Makan Remaja Putri yang Berhubungan dengan Anemia : Kajian Positive Deviance. Amerta Nutr 105-116 (2017).

36. Mahan, L. K., Escott-Stump, S., Raymond, J. L. \& Krause, M. V. Krause's Food \& Nutrition Therapy. (Elsevier Health Sciences, 2012).

37. Sholihah, N., Andari, S. \& Wirjatmadi, B. Hubungan Tingkat Konsumsi Protein, Vitamin C, Zat Besi dan Asam Folat dengan Kejadian Anemia Pada Remaja Putri SMAN 4 Surabaya. Amerta Nutr 135-141 (2019).

38. Almatsier, S., Soetardjo, S. \& Soekatri, M. Gizi Seimbang dalam Daur Kehidupan. (Gramedia Pustaka Utama, 2011).

39. Adriani, M. \& Wirjatmadi, B. Peranan Gizi dalam Siklus Kehidupan. (Kencana Prenada Media Group, 2012).

40. Sirajuddin, S. \& Masni. Kejadian Anemia pada Siswa Sekolah Dasar. Kesmas Natl. Public Heal. J. 9, 264-269 (2015).

41. Kemenkes RI. Pedoman Gizi Seimbang. (Direktorat Jenderal Bina Gizi dan KIA, 2014).
42. Kalsum, U. \& Halim, R. Kebiasaan Sarapan Pagi Berhubungan dengan Kejadian Anemia pada Remaja di SMA Negeri 8 Muaro Jambi. J. Penelit. Univ. Jambi Seri Sains 18, (2016).

43. Balcı, Y. I., Karabulut, A., Gürses, D. \& Çövüt, I. E. Prevalence and Risk Factors of Anemia among Adolescents in Denizli , Turkey. Iran J Pediatr 22, 77-81 (2012).

44. Jalambo, M. O., Hamad, A. \& Abed, Y. Anemia and risk factors among female secondary students in the Gaza Strip. J Public Heal. 21, 271-278 (2013).

45. Gupta, A., Parashar, A., Thakur, A. \& Sharma, D. Anemia Among Adolescent Girls in Shimla Hills of North India: Does BMI and Onset of Menarche Have a Role? Indian J. Med. Sci. 66, 126-130 (2012).

46. WHO. Severe Malaria. Trop. Med. Int. Heal. 19, 7131 (2014).

47. Abanyie, F. A. et al. Ascaris Co-Infection Does Not Alter Malaria- Induced Anaemia in a Cohort of Nigerian Preschool Children. Malar. J. 12, 1-8 (2013).

48. Ahmed, A. et al. The Nutritional Impacts of SoilTransmitted Helminths Infections among Orang Asli Schoolchildren in Rural Malaysia. Parasit \& Vectores 5, (2012).

49. Siva, P. ., Sobha, A. \& Manjula, V. . Prevalence of Anaemia and Its Associated Risk Factors Among Adolescent Girls of Central Kerala. J. Clin. Diagnostic Res. 10, 19-23 (2016).

50. Asres, Y., Yemane, T. \& Gedefaw, L. Determinant Factors of Anemia among Nonpregnant Women of Childbearing Age in Southwest Ethiopia : A Community Based Study. Int. Sch. Res. Not. (2014).

51. Rupali A, P. \& Sanjay S, K. Anemia : Does it Have Effect on Menstruation ? SJAMS 3, 514-517 (2015).

52. Febrianti, Utomo, W. B. \& Adriana. Lama Haid dan Kejadian Anemia pada Remaja Putri. J. Kesehat. Reproduksi 4, 11-15 (2013).

53. Dito. Anemia dan Etiologi Anemia. (Surya Medika, 2007). 